\title{
Long-term monitoring of crab Cardisoma guanhumi (Decapoda: Gecarcinidae) captures in Jobos Bay Estuary, Puerto Rico
}

\section{Yogani Govender ${ }^{1}$}

1. Inter American University of Puerto Rico, P.O. Box 19597, San Juan, Puerto Rico, 00919; ygovender@metro.inter.edu

\author{
Received 02-XI-2018. Corrected 11-III-2019. Accepted 16-VII-2019.
}

\begin{abstract}
The densities of the land crab Cardisoma guanhumi has been declining due to overfishing, habitat degradation and loss, and continued captures in Natural Protected Areas (NPA). Numerous management strategies and regulations have been developed to monitor and reduce population declines. In Puerto Rico, an administrative order of 1999, regulates a closed season, prohibited the capture of crabs through the year from NPA's and below a minimum size for capture $(64 \mathrm{~mm})$. The goal of this research was to monitor spatial-temporal dynamics of crab captures after the implementation of the administrative order. Crabs captured in the Jobos Bay Estuary (JBE) were studied over a 15-year period. The size (carapace width) (CW), sex, and color were documented for 1531 crabs from $31 \mathrm{crab}$ hunters. Significant temporal difference in crab size was observed (Kruskal Wallis = $46.82, \mathrm{P}<6.187^{\mathrm{e}-9}$ ), the smallest crabs were captured in 2004 and the largest crabs were captured in 2013. Crab size varied by color (Kruskal Wallis $=86.54, \mathrm{P}<2.2 \mathrm{e}^{-16}$ ), larger crabs were blue, medium sized crabs were brown and smallest crabs were orange. Since color is related to development stage and market value, color can be used as an educational and enforcement tool. There was significant spatial difference in the size of crabs captured (Kruskal Wallis $=252.54, \mathrm{P}<2.2^{\mathrm{e}-16}$ ), smaller crabs were captured in smaller hunting areas. Only three percent of crabs captured from 2009 to 2018 were below the legal-size limit. Temperature had a weak significant positive relationship with crab size and in years when rainfall was lower smaller crabs were captured. Increases in crab size from 2004 to 2013 coincided with mangrove recovery and the current decrease of crab size coincides with droughts of 2015. Management plans in the Caribbean must include local actions to reduce hunting and climate variability impacts on crab habitat and food availability.
\end{abstract}

Key words: spatial and temporal dynamics; climate variability; land crab fishery.

Govender, Y. (2019). Long-term monitoring of crab Cardisoma guanhumi (Decapoda: Gecarcinidae) captures in Jobos Bay Estuary, Puerto Rico. Revista de Biología Tropical, 67(4), 879-887.

The land crab Cardisoma guanhumi (Lattreille 1825) is a tropical species of ecological, social, and economic importance that is associated to mangroves forests (Govender, Sabat, \& Cuevas, 2008; Hernández-Maldonado \& Campos-Campos, 2015). The species distribution extends from Brazil to Florida (Burggren \& McMahon, 1988) and they are known as keystone species affecting vegetation structure and composition of mangrove forests
(Arroyave-Rincón, Amortegui-Torres, BlancoLibreros, \& Taborda-Marín, 2014; Hines, Lipcius, \& Haddon, 1987). In the Caribbean, specifically in Columbia, Venezuela, Brazil, and Puerto Rico, there is information about population declines and management plans are being developed for the species (CarmonaSuárez, 2011; Firmo, Tognella, Silva, Barboza, \& Alves, 2012; Govender, 2007; Lima, Alves, Fernandes, \& Vieira, 2009). 
Crab population declines have been attributed to overfishing/harvesting, habitat degradation and destruction, and agricultural contamination (Firmo et al., 2012). In Puerto Rico, land crab population numbers have been steadily declining since 1990's (Govender, 2007). Forsee \& Albrecht (2012) and Rodríguez-Fourquet \& Sabat (2009) found that the harvesting was high in Natural Protected Areas (NPA), possibly explaining declining crab size. Govender \& Thomlinson (2010) found that drastic population declines were due to loss of habitat, which is principally mangroves. Land use conversion from mangroves to agriculture and/or urban development coincided with crab population declines. Also, Govender et al., (2008) found that crab abundance and size was affected by changes in micro-climatic conditions in different land use/landcover types, with grasslands having lower abundance than mangrove and forested areas due to higher soil temperatures. Govender (2007) concluded that the combined effects of changes in land use and hunting have resulted in population declines for the past decades.

Based on anecdotal information, the Puerto Rico Department of Natural and Environmental Resources (DNER) placed an administrative order in 1999 that included: 1) prevention of capture in Natural Protected Areas (NPA), 2) enforcing a closed season from 15 July to 15 October, and 3) a lower size limit of $64 \mathrm{~mm}$ $\mathrm{CW}$ for captures, well above the first sexual maturity size of $53 \mathrm{~mm} \mathrm{CW}$ for the females and $52 \mathrm{~mm}$ for the males (Silva, Schwamborn, \& Oliveira, 2014). The goal of this research project was to monitor the impact of the administrative order on crab populations. A long-term monitoring project was developed at Jobos Bay National Estuary Research Reserve (JBNERR) with the following objectives: 1) to understand the temporal differences in the size and color of crabs captured in communities surrounding the Jobos Bay Estuary (JBE); 2) to determine the spatial differences in the size of crabs captured in surrounding areas of the JBE; 3 ) to monitor the difference in crabs size captured by crab hunters over a period of 10 years; and 4) to understand the relationship between crab size, hunting area size, and climate variability.

\section{MATERIAL AND METHODS}

Study Site: In 1981, NOAA designated Jobos Bay Estuary a National Estuarine Research Reserve (NERR), the only NERRs site in Puerto Rico and the wider Caribbean. The Jobos Bay estuary is found in the South East coast of Puerto Rico in the municipalities of Salinas and Guayama (17 $57^{\prime} 01^{\prime \prime}$

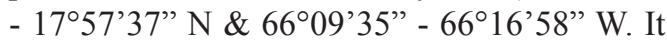
covers an area of approximately 2800 acres of coastal ecosystems. Jobos Bay Estuary (JBE) is on the leeward side on the island of Puerto Rico, characterized by a mean annual rainfall that ranges from a minimum of $600 \mathrm{~mm}$ to a maximum of $1100 \mathrm{~mm}$ (Ewel \& Whitmore, 1973). Mangroves are the dominant vegetation cover of the JBE ecosystem and during the 1990's hydrological changes, due to agricultural practices in the watershed caused mangrove forest die-offs (Govender, 2007). The rich protected substrate of mangroves provides habitat for a large variety of commercially and recreationally important organisms such as finfish and shellfish species and nesting sites for native and migratory birds (Jobos Bay Management Plan, 2017).

This study was carried out within six communities in JBE viz: Puerto de Jobos, Miramar, Mosquito, San Felipe, Aguirre, and Las Maréas (from east to west). Thirty-one crab hunters participated during the 15 year-period from 2004, 2006, 2009, 2010, and 2012-2018. Once identified, crab hunters were asked permission to measure the size (carapace width -CW and length-CL), sex, side of the dominant chela and color of crabs they captured. Crabs were measured in March of each year because they emerge from molting after the first rains (Govender, 2007). Crab size was measured using a SPI Plastic Dial Caliper that measures up to $150 \mathrm{~mm}$. The sex of $C$. guanhumi can be easily identified, as the female abdomen is significantly wider than the males (Buggren \& McMahon, 1988). After crabs were measured, 
they were removed from the cage until at least ten crabs per crab hunter was measured. To avoid crab hunter bias, crabs were randomly selected by the researcher or student assistant. As crab hunters gained confidence in the researchers, they allowed the research team to measure more than ten crabs per cage (Table 1). A unique number was assigned to crab hunters to ensure their privacy.

Since, data for crab size (CW) was not normally distributed (Shapiro Test $\mathrm{W}=0.99$, $\mathrm{P}<0.010)$ therefore non-parametric tests were used (Sokal \& Rohlf, 1981) for statistics analysis. To determine the temporal and spatial differences of crab size in the JBE Kruskal Wallis Tests were used. To determine if there was any relationship between the estimated size of hunting area and crab size, we asked crab hunters to identify on a map the areas where they set their traps. Interpretation of estimated hunting areas size were delimited using the satellite image of 2018 (Google Maps, 2018). Since crab hunters shared three common hunting areas the six communities were pooled into the following geographical categories viz. Las Mareas for the West, Aguirre, Mosquito and San Felipe for Central and Puerto de Jobos and Miramar for the East. A Spearman correlation analysis was done to determine differences in crab size by the three-geographic locations. A Kruskal Wallis Test was used to determine differences in crab size between crab hunters. Not enough information on site or crab hunter identification was collected in 2004 and 2006 and therefore were not used in analysis for size differences among crab hunters and between sites.

Climate data were requested from National Oceanographic and Atmospheric Administration NOAA-NERRS Centralized Data Management Office for the period 2004 through 2017 (NERRS, 2018). A Spearman correlation was used to determine the relationship between annual average rainfall and accumulated total rainfall by year and temperatures (average, minimum, and maximum) with average crab size at JBE. Since temperature variables were auto-correlated only average temperatures were used in further analyses. Statistical analysis was done using RStudio, Ver.1 1.442 20092018 (R Core Team, 2014).

\section{RESULTS}

In the fifteen years of the study, 1531 individual crabs were measured within the six communities surrounding the JBNERR. Since Govender and Rodriguez, (2003) found significant correlation between $\mathrm{CW}$ and $\mathrm{CL}(\mathrm{CW}=$ $\left.0.7257 \mathrm{CL}+8.4225 \mathrm{R}^{2}=0.802\right)$, only $\mathrm{CW}$ was used for further analysis of size. Average size of CW was $71.3 \mathrm{~mm}$. There were 494 females and 655 males, however for 382 crabs, sex was not documented. Males were significantly larger in size $($ Chi Square $=61.71, \mathrm{P}<3.99$ $\left.\mathrm{e}^{-15}\right)$. The mean size for females was $73.7 \mathrm{~mm}$ (Standard Deviation, SD $=11.4$ Number of individuals, $\mathrm{N}=494$ ) and for males $78.5 \mathrm{~mm}$ $(\mathrm{SD}=3.9, \mathrm{~N}=655)$.

There was no significant difference on the side of the dominant chela, with 302 crabs on the left-hand side and 340 on the right-hand side (Chi Square $=2.012, \mathrm{P}=0.156$ ). For nine individuals both the left and right-side chela was of the same size. There was significant difference in crab size by color (Kruskal Wallis $\left.=86.54, \mathrm{P}<2.2 \mathrm{e}^{-16}\right)$, larger crabs were blue (Median $\mathrm{CW}=81.85 \mathrm{~mm}, \mathrm{SD}=9.8, \mathrm{~N}=574$ ), medium sized crabs were brown $(77.8 \mathrm{~mm}, \mathrm{SD}$ $=9.8, \mathrm{~N}=233)$ and smallest crabs were orange (74.5 mm, $\mathrm{SD}=8.7, \mathrm{~N}=196)$.

Temporal dynamics in crab size: There is a significant difference in crab size $(\mathrm{CW})$ within the JBE from 2004 until 2018 (Kruskal Wallis $=832.7, \mathrm{P}<2.2 \mathrm{e}^{-16}$ ) (Fig. 1). Crab size in 2004 and 2006 was smaller from the rest of the years studied (Table 1). The average size of crabs captured at JBE is $75.7 \mathrm{~mm}$. Crab hunters captured crabs in all size ranges during the study period. Of those, 133 crabs were below legal limit of $64 \mathrm{~mm}$ (Fig. 2). The smallest crab was captured in 2004 with a CW of $36 \mathrm{~mm}$ and the largest crab was captured in 2013 with a CW of $113 \mathrm{~mm}$ (Table 1). In this study, there was a increase in crab size from 2004 until 2013 and a decrease in crab size from 2014 to 
TABLE 1

Carapace width (CW) (mm) of Cardisoma guanhumi captured in Jobos Bay Estuary from 2004 through 2018

\begin{tabular}{ccccc} 
Year & $\mathrm{N}$ & Average $\mathrm{CW} \pm \mathrm{SD}$ & Minimum & Maximum \\
2004 & 439 & $55.6 \pm 9.5$ & 36.0 & 93.5 \\
2006 & 86 & $58.0 \pm 9.4$ & 38.0 & 87.0 \\
2009 & 161 & $73.7 \pm 9.3$ & 55.2 & 103.0 \\
2010 & 150 & $79.2 \pm 8.6$ & 59.0 & 104.0 \\
2012 & 101 & $85.5 \pm 9.8$ & 64.7 & 111.0 \\
2013 & 101 & $85.8 \pm 9.0$ & 66.5 & 113.0 \\
2014 & 102 & $82.9 \pm 10.4$ & 65.5 & 108.1 \\
2015 & 136 & $80.3 \pm 7.9$ & 50.7 & 99.5 \\
2016 & 99 & $76.1 \pm 9.7$ & 48.0 & 98.2 \\
2017 & 86 & $79.5 \pm 7.9$ & 64.3 & 99.9 \\
2018 & 68 & $75.7 \pm 10.9$ & 55.5 & 101.5 \\
Total & 1529 & $71.3 \pm 9.3$ & 54.9 & 101.7 \\
\hline
\end{tabular}

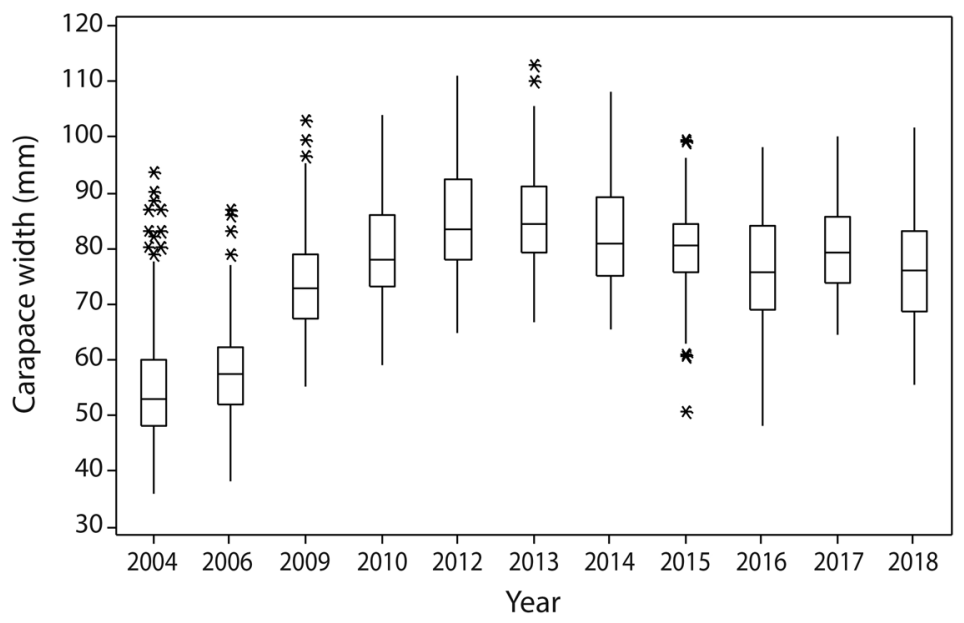

Fig. 1. Temporal dynamics of crab size $(\mathrm{mm})$ from 2004 through 2018 of crabs captured in six communities surrounding the Jobos Bay Estuary, Puerto Rico. Boxplot shows the median; 75 and 25 quartiles, whiskers show maximum and minimum $\mathrm{CW}$ and the asterisk show outliers.

2018 (Fig. 1). Between 2014 and 2016 there was a $6.8 \mathrm{~mm}$ decrease in average crab size and by 2018 there is a $7.22 \mathrm{~mm}$ decrease of crab size when compared to average crab size of 2014 (Table 1).

Spatial dynamics of crab size: There was significant difference in size of crab within six communities along the JBE (Kruskal Wallis = 46.82, $\left.\mathrm{P}<6.187^{\mathrm{e}-9}\right)$. The size of three hunting areas in the JBE was different, in the Western hunting area was $0.17 \mathrm{~km}^{2}$, in the central sites hunting area was $1.34 \mathrm{~km}^{2}$ and in the Eastern sites hunting area was $2.5 \mathrm{~km}^{2}$. Crabs captured in the community of Puerto de Jobos in the East $(\mathrm{N}=168)$ were on average larger than those captured from Las Mareas in the West $(\mathrm{N}=96)$. Of the 1443 crabs captured from 2009 to 2018, 49 crabs (3\%) were below the legal-size limit. The under sized crabs were captured by ten of the 31 crab hunters (Fig. 2). Crab hunters 1 and 23 were from the Las Mareas (West) community collected the smallest crabs followed by crab hunters $10,15,19$, and 24 from the 
communities of Puerto de Jobos and Miramar (East) and crab hunter 25 was from Aguirre (Central) (Fig. 2).

There were significant differences in the size of crabs captured by crab hunters (Kruskal Wallis $=252.54, \mathrm{P}<2.2 \mathrm{e}-16$ ) (Fig. 2). Crab hunter 23 on average captured smaller crabs with average size of $69 \mathrm{~mm}(\mathrm{~N}=56)$ while crab hunter 9 captured larger individuals with average size of $92.3 \mathrm{~mm}(\mathrm{~N}=11)$. Although there was no correlation between the size of the hunting area and the size of crabs (Spearman correlation $=0.772, \mathrm{P}=0.072$ ), crab hunters using smaller hunting areas in the west captured smaller individuals.

Relationship of crab size with climate: There were no significant differences for monthly accumulated rainfall (Kruskal Wallis $=19.69, \mathrm{P}=0.103)$ and monthly average temperature (Kruskal-Wallis $=8.87, \mathrm{P}=0.782$ ) among years at JBE (Table 2). The lowest accumulated rainfall recorded was during the years 2009 (538 mm), 2013 (547 mm) and 2015 (551 $\mathrm{mm})$. The highest accumulated annual rainfall recorded at JBE was in 2010 (1413 mm), 2011 $(1413 \mathrm{~mm})$ and in $2012(1518 \mathrm{~mm})$ (Table
2 ). The highest monthly rainfall recorded at JBE was $640 \mathrm{~mm}$ in September 2008 when tropical storm "Jean" passed through the South East of the island. In September 2017 when hurricane "Maria" passed through the island the JBE received a total monthly rainfall of $435 \mathrm{~mm}$. Although, there was no correlation between crab size and average annual rainfall (Spearman correlation coefficient $=0.281$ ) or total accumulated annual rainfall(Spearman correlation coefficient $=0.128$ ), we observed small crab sizes in the years 2004, 2006, 2009 and 2015, with lower rainfall (Table 2). There was significant correlation between crab size and average temperature (Spearman correlation coefficient $=0.791, \mathrm{P}=0.004)$. The average temperature for study period was $26.4 \pm$ $1.6{ }^{\circ} \mathrm{C}$. The highest temperatures recorded at JBE were $28.3^{\circ} \mathrm{C}$, recorded consecutively from 2012 until 2015. The lowest temperature was recorded in 2006 with $24.5^{\circ} \mathrm{C}$ (Table 2).

\section{DISCUSSION}

Color of C. guanhumi can be a useful educational tool to reduce the number of under

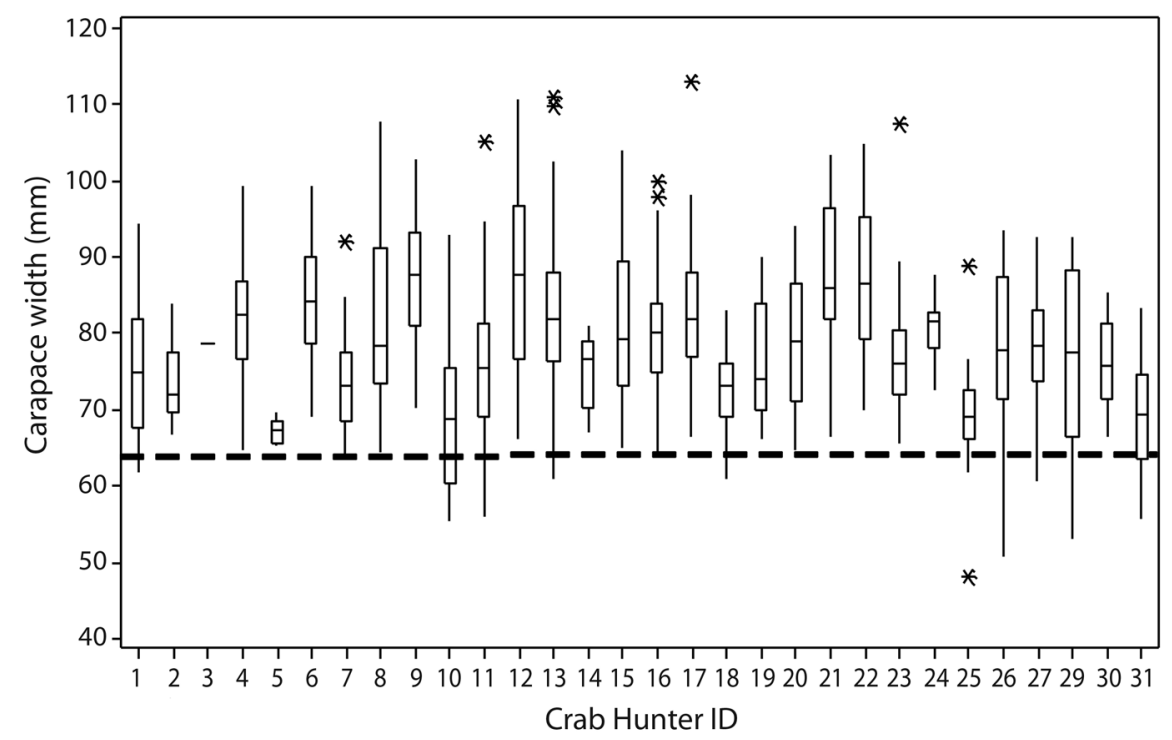

Fig. 2. Difference in size of crabs captured by crab hunter from 2009 to 2018 in the Jobos Bay Estuary, Puerto Rico. The black dashed line shows the legal capture size allowed in Puerto Rico. Boxplot shows the median; 75 and 25 quartiles, whiskers show maximum and minimum $\mathrm{CW}$ and the asterisk show outliers. 
TABLE 2

Climate variables in relation to carapace width (CW) of C. guanhumi at Jobos Bay Estuary from 2004 through 2017

\begin{tabular}{ccccccc} 
& $\begin{array}{c}\text { Average CW } \\
(\mathrm{mm})\end{array}$ & $\begin{array}{c}\text { Average annual } \\
\text { rainfall }(\mathrm{mm})\end{array}$ & $\begin{array}{c}\text { Annual accumulated } \\
\text { rainfall }(\mathrm{mm})\end{array}$ & $\begin{array}{c}\text { Min temp } \\
\left({ }^{\circ} \mathrm{C}\right)\end{array}$ & $\begin{array}{c}\text { Max temp } \\
\left({ }^{\circ} \mathrm{C}\right)\end{array}$ & $\begin{array}{c}\text { Average temp } \\
\left({ }^{\circ} \mathrm{C}\right)\end{array}$ \\
\hline 2004 & 55.59 & 75.3 & 903 & 24.1 & 27.7 & 26.1 \\
2005 & No data collected & 98.5 & 1182.5 & 23.5 & 27.9 & 26.2 \\
2006 & 56.31 & 69.3 & 831.9 & 24.3 & 27.5 & 26.2 \\
2007 & No data collected & 91.5 & 1023.8 & 24.9 & 27.8 & 26.4 \\
2008 & No data collected & 88.4 & 1061.4 & 24.1 & 28.0 & 25.9 \\
2009 & 73.66 & 44.8 & 537.7 & 23.9 & 28.2 & 26.3 \\
2010 & 79.15 & 117.8 & 1413.6 & 24.3 & 27.7 & 26.4 \\
2011 & No data collected & 117.8 & 1517.7 & 24.6 & 27.7 & 26.2 \\
2012 & 85.49 & 126.5 & 547 & 24.9 & 28.1 & 26.7 \\
2013 & 85.79 & 45.6 & 1013.6 & 24.9 & 28.3 & 26.6 \\
2014 & 82.88 & 84.5 & 744.7 & 25.2 & 28.3 & 26.7 \\
2015 & 80.32 & 45.9 & 551.2 & 25.5 & 28.3 & 27.0 \\
2016 & 76.11 & 75.3 & 904.1 & 25.1 & 28.3 & 26.6 \\
2017 & 79.53 & 111.7 & 1340 & 24.7 & 28.3 & 26.5 \\
\hline
\end{tabular}

sized crabs being captured and sold. C. guanhumi color and size patterns found at JBE coincide with color patterns found in Brazil. Silva, Schwamborn, \& Oliveira (2014) found that the color is related to developmental stage. Smaller individuals had a bright orange color while adults at sexual maturity were brown to blue. In Puerto Rico, the color of crabs is important in determining the market price. Govender (2007) found crab hunters would sell blue crabs at higher price than orange colored individuals because of larger size. Also, crabs sold by local crab hunters usually have a wide array of color patterns while those imported into Puerto Rico were always blue. Crabs that are blue were above $64 \mathrm{~mm}$, the legal-size limit (Govender, 2007). Interestingly, although the crab color patterns of C. guanhumi varies, the common name for this species in Puerto Rico is "Juey Azul" which means "blue crabs". It may be historically only blue crab were captured and sold and therefore the colloquial name. Due to declining numbers crab hunters are capturing crabs of different colors (Govender, 2007). Thus, color can be useful educational and resource management tool. Law enforcement agents who monitor crab captures, could use crab color as a quick indicator of crab size.
Studies in Puerto Rico show a decrease in crab size since the 1950's. The average size of crabs captured between 1957 and 1958 was $86.1 \mathrm{~mm}$ (Feliciano, 1962) and $56.4 \mathrm{~mm}$ in 2002 (Govender \& Rodríguez-Fourquet, 2008). The results of this long-term study indicate that the crab size did increase between 2004 and 2013 but since 2013 crab size has been steadily declining. This study and the results of Rodríguez-Fourquet and Sabat (2009) showed that crab hunting is taking place within NPA's in JBE and around Puerto Rico. While managers at the JBNERR have additional local management actions such as fencing, educational signs, removal of traps and increased patrolling to manage C. guanhumi within the NPA's, there has been little impact on the reduction of illegal activities such as overfishing (Jobos Bay Management Plan, 2017).

With urban development and agriculture around the JBE replacing crab habitat (Govender, 2007; Govender \& Thomlinson, 2010), the remaining areas to capture crabs are within NPA's. While majority of crab hunters are aware of size restrictions they continued to capture smaller crabs because the rely on the supplementary income from crab fishery. The market value of crabs depends on size so while 
selling smaller crabs is not as lucrative, the time and effort required to capture crabs forces crab hunters to remove and sell them (Govender, 2007). Decreasing crab sizes can therefore be explained by crab hunter behavior at JBE that follows the "tragedy of the commons" principle due to market demand.

The spatial distribution of capture size can be explained by changes to the landuse/ landcover and habitat loss (Govender \& Thomlinson, 2010). The cause of habitat loss at JBE is two fold, anthropogenic conversion of land from mangroves to urban development or agriculture and impacts of sea level rise due to climate change. Numerous studies show that highest densities of C. guanhumi were associated with mangroves forests (Govender \& Thomlinson, 2010; Govender et al., 2008; Carmona-Suárez \& Guerra-Castro, 2012). During the years 2004 to 2012 the increase of crab size coincides with the mangroves recovery.

After the passing of hurricane George in 1998, mangrove die-off was observed within the six communities at JBE. The mangrove forests of Aguirre, Miramar and Puente de Jobos were not as severely damaged (Jobos Bay Management Plan, 2017) and therefore are inhabited by larger crabs. The steady regrowth of mangroves since the hurricane probably improved crab habitat by increasing availability of food and reducing burrow temperatures (Govender et al., 2008; Li et al., 2015) which allows crab growth and size increase. Areas to the west such as Las Mareas and Mar Negro are converting into a salt flats (Jobos Bay Management Plan, 2017) and thus reducing crab habitat and food availability. The cascading effect of smaller habitat availability results in higher hunting pressure and therefore smaller crabs being captured in the west. Therefore, to increase crab size, habitat management rather than species management must be considered.

The temporal dynamics of size of crabs captured can be explained by the inter annual temperature patterns at JBE. Although there was no signifcant correlation between crab size and rainfall at JBE, it can be observed in years with higher rainfall that crab size was higher and years when higher temperatures were recorded crab size was lower. The decrease in size from 2015 may be explained by changes in rainfall regimes and increased temperatures (Table 2). The droughts of 2015 changed the hydrology causing mangrove die-offs. The reduction of food availability and increase in micro-climatic stress may result in reduced growth of C. guanhumi. Govender et al., (2008) found that crabs are relatively sensitive to changes in micro-climatic variables especially soil surface temperatures. With increasing mangrove die-offs crab burrows become exposed to higher temperatures and increasing air temperatures that are linked to reduced body sizes of ectotherms (Jaramillo et al., 2017).

Climate variability may explain the spatial and temporal dynamics of crab size in JBE. Hunting presure at JBE seems constant, with no new crab hunters entering the fishery in the past 10 years (pers. obs), but variability in climate poses a major threat on land crab fishery due to habitat loss. It is expected that mangroves of the Anthropocene will be on the move because sea level rise (SLR) and atmospheric warming. SLR will inundate and drown some mangrove areas and will stimulate the landward movement of mangroves where conditions allow it (Lugo, Medina, \& McGinley, 2014). Therefore, to conserve this economically and culturally important species in Puerto Rico and the Caribbean, the management plans must include local actions to reduce the huting pressure, the impact of landuse changes on the delicate hydrological balance in watershed and increase reforestation efforts to ensure the survial of mangroves (Govender, 2007; Li et al., 2015). The future of the C.guanhumi fishery in the Caribbean, warrants a revision of regulations to include protection of land crab habitat.

Ethical statement: the author declares that she agrees with this publication; that there is no conflict of interest of any kind; and that she followed all pertinent ethical and legal procedures and requirements. All financial sources are fully and clearly stated in the 
acknowledgements section. A signed document has been filed in the journal archives.

\section{ACKNOWLEDGMENTS}

I thank the 31 crab hunters who contributed towards this study, Daniel Davila Casanova, Dra. Claudia Patricia Ruiz Diaz for statistical analysis, friends and students from University of Puerto Rico and Inter American University, who volunteered to carry out field work.

\section{RESUMEN}

Monitoreo a largo plazo de las capturas del cancrejo Cardisoma guanhumi (Decapoda: Gecarcinidae) en el estuario de la Bahía de Jobos, Puerto Rico. Las densidades del cangrejo terrestre Cardisoma guanhumi ha disminuido debido a la sobrepesca, la degradación y pérdida de hábitat y la captura continua en áreas naturales protegidas (ANP). Se han desarrollado numerosas estrategias y regulaciones de gestión para monitorear y reducir el declive de la población. En Puerto Rico, una orden administrativa de 1999 regula una temporada cerrada, prohibió la captura de cangrejos durante todo el año en las ANP y por debajo de un tamaño mínimo para la captura (64 mm). El objetivo de esta investigación fue monitorear la dinámica espacio-temporal de las capturas de cangrejo después de la implementación de la orden administrativa. Los cangrejos capturados en el estuario de la Bahía de Jobos (JBE) se estudiaron durante un período de 15 años. El tamaño (ancho del caparazón) (CW), el sexo y el color se documentaron para 1531 cangrejos de 31 cazadores de cangrejos. Se observó una diferencia temporal significativa en el tamaño del cangrejo (Kruskal Wallis $=46.82, \mathrm{P}<$ 6.187e-9), los cangrejos más pequeños se capturaron en 2004 y los cangrejos más grandes en 2013. El tamaño del cangrejo varió según el color (Kruskal Wallis $=86.54$, $\mathrm{P}<2.2 \mathrm{e}-16$ ), los cangrejos más grandes eran azules, los cangrejos medianos eran marrones y los cangrejos más pequeños eran anaranjados. Dado que el color está relacionado con la etapa de desarrollo y el valor de mercado, el color se puede utilizar como herramienta educativa y de cumplimiento. Hubo una diferencia espacial en el tamaño de los cangrejos capturados (Kruskal Wallis $=252.54, \mathrm{P}<$ 2.2e-16), se capturaron cangrejos más pequeños en áreas de caza pequeñas. Solo el tres por ciento de los cangrejos capturados de 2009 a 2018 estaban por debajo del límite de tamaño legal. La temperatura tuvo una relación positiva significativa con el tamaño del cangrejo, cuando la lluvia fue menor, se capturaron cangrejos pequeños. Los aumentos en el tamaño de los cangrejos de 2004 a 2013 coincidieron con la recuperación de los manglares y la disminución actual del tamaño de los cangrejos coincide con las sequías de 2015. Los planes de manejo en el Caribe deben incluir acciones locales para reducir la caza y los impactos de la variabilidad del clima en el hábitat del cangrejo y la disponibilidad de alimentos.

Palabras clave: dinámica de caza espacio-temporal; variabilidad del clima; cangrejo terrestre.

\section{REFERENCES}

Arroyave-Rincón, A., Amortegui-Torres, V., Blanco-Libreros, J. F., \& Taborda-Marín, A. (2014). Edge effect on blue crab population Cardisoma guanhumi (Decapoda: Gecarcinidae) in the mangrove of El Uno Bay, Uraba Gulf (Colombia): an approximation to the folk catchery. Actual Biology, 36(100), 47-57.

Burggren, W. W., \& McMahon, B. R. (1988). Biology of the land crabs: An introduction. In W. W. Burggren \& B. R. McMahon (Eds.), Biology of the Land Crabs (pp. 1-5). Cambridge, UK: Cambridge University Press.

Carmona-Suárez, C. (2011). Present status of Cardisoma guanhumi Latreille, 1828 (Crustacea: Brachyura: Gecarcinidae) populations in Venezuela. Interciencia, 36(12), 908-913.

Carmona-Suárez, C., \& Guerra Castro, E. (2012). Comparison of three quick methods to estimate crab size in the land crabs Cardisoma guanhumi and Ucides cordatus (Crustacea: Brachyura: Gecarcinidae and Ucididae). Revista Biología Tropical, 60, 139-149.

Ewel, J. J., \& Whitmore, J. L. (1973). The ecological life zones of Puerto Rico and the U.S. Virgin Islands. Rio Piedras, Puerto Rico: USDA Forest Service, Institute of Tropical Forestry.

Feliciano, C. (1962). Notes on the Biology and economic importance of Cardisoma guanhumi (Latreille) Puerto Rico. San Juan, Puerto Rico: Department of Agriculture Puerto Rico.

Firmo, A. M. S., Tognella, M. M. P., Silva, S. R., Barboza, R. R. R. D., \& Alves, R. R. N. (2012). Capture and commercialization of blue land crabs ("guaiamum") Cardisoma guanhumi (Lattreille, 1825) along the coast of Bahia State, Brazil: An ethnoecological approach. Journal of Ethnobiology and Ethnomedicine, 8(12), 1-12.

Forsee, R. A., \& Albrecht, M. (2012). Population estimation and site fidelity of the land crab Cardisoma guanhumi (Decapoda: Brachyura: Gecarcinidae) on Vieques Island, Puerto Rico. Journal of Crustacean Biology, 32(3), 435-442.

Google Maps. (2018). Jobos Bay Estuary, Puerto Rico. Retrieved from https://www.google.com/maps/ place/Bah\%C3\%ADa+de+Jobos/@17.9413255,$66.2278941,7764 \mathrm{~m} /$ data $=! 3 \mathrm{~m} 1 ! 1 \mathrm{e} 3 ! 4 \mathrm{~m} 5 ! 3 \mathrm{~m} 4$ ! $1 \mathrm{~s} 0 \mathrm{x} 8$ 
c1cb5b6307f9dd9:0x8e99d4cc4a269f74!8m2!3d17.9 462376!4d-66.1920943

Govender, Y. (2007). A multidisciplinary approach towards understanding the distribution, abundance and size structure of the land crab Cardisoma guanhumi (Latreille, 1825) in two estuaries in Puerto Rico (Doctoral Thesis). University of Puerto Rico, Puerto Rico.

Govender, Y., \& Rodríguez-Fourquet, C. (2008). Techniques for rapid assessment of population density and body size of the land crab Cardisoma guanhumi (Latreille, 1825) in Puerto Rico. Journal of Tropical Estuaries, 1(1), 9-15.

Govender, Y., Sabat, A. M., \& Cuevas, E. (2008). Effects of land-use/land-cover changes on land crab, Cardisoma guanhumi, abundance in Puerto Rico. Journal of Tropical Ecology, 24(4), 417-423.

Govender, Y., \& Thomlinson, J. (2010). Changes in land use/landcover affect distribution and habitat of the land crab, Cardisoma guanhumi (Gecarcinidae, Decapoda) in two estuaries in Puerto Rico. Caribbean Journal of Science, 46(2-3), 258-266.

Hernández-Maldonado, A., \& Campos-Campos, N. H (2015). Estado actual de la población adulta del cangrejo semi-terrestre Cardisoma guanhumi (Latreille) en la Isla de San Andrés, Caribe colombiano. Boletín de Investigaciones Marinas y Costeras, 44(1), 185-198.

Hines, S, A. H., Lipcius, R. N., \& Haddon, A. M. (1987). Population dynamics and habitat partitioning by size, sex, and molt stage of blue crabs Callinectes sapidus in a sub-estuary of central Chesapeake Bay. Marine Ecology-Progress Series, 36, 55-64

Jaramillo, E., Dugan, J. E., Hubbard, D. M, Contreras, H., Duarte, C., Acuña, E., \& Schoeman, D. S. (2017). Macroscale patterns in body size of intertidal crustaceans provide insights on climate change effects. PLoS ONE, 12(5), e0177116. DOI: 10.1371/journal. pone. 0177116
Jobos Bay Management Plan. (2017). Plan de Manejo Reserva Nacional de Investigación Estuarina Bahía de Jobos (JBNERR) 2017-2022 Final. Retrieved from http://drna.pr.gov/jbnerr/plan-de-manejo-reservanacional-de-investigacion-estuarina-bahia-de-jobosjbnerr-2017-2022-final/

Lima, J. F., Alves, S. T. M., Fernandes, M. E. B., \& Vieira, I. M. (2009). First records of Cardisoma guanhu$m i$ (Decapoda, Brachyura, Gecarcinidae) from the coast of Brazilian Amazonia. Crustaceana, 82(11), 1463-1468.

Li, W., Cui, L., Zhang, M., Wang, Y., Zhang, Y., Lei, Y., \& Zhao, X. (2015). Effect of mangrove restoration on crab burrow density in Luoyangjiang Estuary, China. Forest Ecosystems, 2(21), 2-9.

Lugo, A. E., Medina, E., \& McGinley, K. (2014). Issues and challenges of mangrove conservation in the Anthropocene. Madera y Bosques, 20, 11-38.

NOAA National Estuarine Research Reserve System (NERRS). (2018). System-wide Monitoring Program. Data accessed from the NOAA NERRS Centralized Data Management Office. Retrieved from: http:// www.nerrsdata.org

R Core Team. (2014). R: A language and environment for statistical computing. R Foundation for Statistical Computing, Vienna, Austria. Retrieved from https:// www.R-project.org/

Rodríguez-Fourquet, C., \& Sabat, A. M. (2009). Effect of harvesting, vegetation structure and composition on the abundance and demography of the land crab Cardisoma guanhumi in Puerto Rico. Wetlands Ecology and Management, 17, 627-640.

Sokal, R. R., \& Rohlf, F. J. (1981). Biometry (2nd ${ }^{\text {ed }}$ ). San Francisco, USA: Freeman.

Silva, C., Schwamborn, R., \& Oliveira, J. L. (2014). Population biology and color patterns of the blue land crab, Cardisoma guanhumi (Latreille 1828) (Crustacea: Gecarcinidae) in the Northeastern Brazil. Brazilian Journal of Biology, 74(4), 949-958. 